\section{Outcome of pregnancies associated with raised serum and normal amniotic fluid $\alpha$ fetoprotein concentrations}

Open neural tube defects are associated with raised concentrations of $\alpha$ fetoprotein in amniotic fluid and maternal serum. Raised maternal serum $\alpha$ fetoprotein concentrations have also been associated with fetal distress, intrauterine death, threatened abortion, multiple pregnancy, exomphalos, congenital nephrosis, Turner's syndrome, and low birthweight (preterm) infants. On analysing perinatal and maternal morbidity in south Gwent we noted that pregnancies in which $\alpha$ fetoprotein concentrations were high in serum but normal in amniotic fluid seemed to have an increased incidence of complications. We carried out a prospective study to investigate this phenomenon further.

\section{Patients, methods, and results}

From August 1978 to June 1980, 4864 women were booked for delivery and 2913 were screened for neural tube defects at 16-18 weeks' gestation by estimation of serum $\alpha$ fetoprotein concentrations (Amersham radioimmunoassay technique). If the concentration was abnormal the estimation was repeated within one week when possible, and gestation was assessed ultrasonically. Amniocentesis was performed in those patients in whom the serum $\alpha$ fetoprotein concentration was high on two occasions ( $>95$ th centile for gestational age). Those patients with normal amniotic fluid concentrations were reassured and continued their pregnancies.

The outcome of pregnancy in these women with normal amniotic fluid concentrations $(n=55)$ was compared with that in a group of controls comprising 165 consecutive women delivering in the delivery unit during the period of the study. The control group had normal serum $\alpha$ fetoprotein concentrations and did not undergo amniocentesis. The groups were compared for the incidences of severe pre-eclampsia, antepartum haemorrhage, preterm labour, induction, birth weight if less than $2500 \mathrm{~g}$ or less than the 10th centile for gestation, Apgar score, gestational age at delivery, fetal abnormalities, and neonatal mortality. They were also compared for maternal age, weight, height, parity, and social class assessed according to the husband's occupation. Comparison was with the $\chi^{2}$ test or Fisher's exact test (two tailed) when indicated.

Distributions and ranges of age, weight, parity, and social class were similar in both groups. No neural tube defects arose in either group, and fetal abnormalities that did occur were various and relatively minor, such as hypospadias. The incidences of preterm labour, low birth weight, fetal abnormalities, and perinatal mortality were significantly higher in the study group (table). Incidences of antepartum haemorrhage, assisted delivery, severe pre-eclampsia, low Apgar scores, and light for dates infants were also higher but did not reach significance. Three perinatal deaths occurred: there was one unexplained stillbirth, and two deaths were due to the respiratory distress syndrome in preterm infants.

Incidences of complications of pregnancy in women with high maternal serum but normal amniotic fluid $\alpha$ fetoprotein concentrations and controls

\begin{tabular}{|c|c|c|c|c|}
\hline & $\begin{array}{l}\text { Study group } \\
(\mathrm{n}=55)\end{array}$ & $\begin{array}{l}\text { Controls } \\
(n=165)\end{array}$ & $\begin{array}{l}\text { Statistical } \\
\text { test }\end{array}$ & $\mathbf{p}$ \\
\hline $\begin{array}{l}\text { Preterm labour } \\
\text { Severe pre-eclampsia } \\
\text { Antepartum haemorrhage } \\
\text { Assisted delivery (forceps) } \\
\text { Low birth weight: }\end{array}$ & $\begin{array}{l}8 \\
8 \\
5 \\
7\end{array}$ & $\begin{array}{r}9 \\
11 \\
8 \\
9\end{array}$ & $\begin{array}{l}\chi^{2}=4 \cdot 78 \\
\chi^{2}=3 \cdot 25 \\
\text { Fisher } \\
\chi^{2}=3 \cdot 24\end{array}$ & $\begin{array}{l}<0.05 \\
\text { NS } \\
\text { NS } \\
\text { NS }\end{array}$ \\
\hline $\begin{array}{l}<2500 \mathrm{~g} \\
<10 \text { th centile }\end{array}$ & $\begin{array}{l}8 \\
4\end{array}$ & $\begin{array}{l}9 \\
3\end{array}$ & $\begin{array}{l}\chi^{2}=4 \cdot 78 \\
\text { Fisher }\end{array}$ & $\begin{array}{l}<.05 \\
\text { NS }\end{array}$ \\
\hline $\begin{array}{l}\text { Apgar score at } 1 \mathrm{~min}: \\
<5 \\
<8 \\
\text { Perinatal death } \\
\text { Fetal abnormality }\end{array}$ & $\begin{array}{r}8 \\
10 \\
3 \\
4\end{array}$ & $\begin{array}{r}14 \\
34 \\
0 \\
1\end{array}$ & $\begin{array}{l}\chi^{2}=1.68 \\
\chi^{2}=0.15 \\
\text { Fisher } \\
\text { Fisher }\end{array}$ & $\begin{aligned} & \text { NS } \\
& \text { NS } \\
&<0.05 \\
&<0.05\end{aligned}$ \\
\hline
\end{tabular}

\section{Comment}

High incidences of preterm labour and of infants of low birth weight in women with raised serum $\alpha$ fetoprotein concentrations have been noted in other studies, ${ }^{1-3}$ and our figures, though small, support these findings and further suggest that the incidences of fetal abnormality and perinatal death are also increased in these women. The effect of amniocentesis on our results is difficult to evaluate. Previous studies, though reporting an increased incidence of antepartum haemorrhage and respiratory distress syndrome, have not shown any increase in the incidences of preterm labour, intrauterine growth retardation, pre-eclampsia, or fetal compromise. ${ }^{45}$

We suggest that patients with high serum and normal amniotic fluid $\alpha$ fetoprotein concentrations constitute an at risk group and should therefore be carefully monitored during pregnancy and labour.

We gratefully acknowledge the help and advice of $\mathrm{Mr}$ I Rocker, $\mathrm{Mr} \mathrm{R}$ Golding, Mr D G Daniel, and Mr J Bowen, consultant obstetricians at this hospital; and of Mr R G Newcombe, University Hospital of Wales, for the statistical analysis.

${ }^{1}$ Brock DJH, Barron L, Jelen P, Watt M, Scrimgeour JB. Maternal serum alpha fetoprotein measurements as an early indicator of low birth weight. Lancet 1977 ;ii:267-8.

${ }^{2}$ Wald NJ, Cuckle H, Stirrat GM, Turnbull AC. Maternal serum alpha fetoprotein and birth weight in twin pregnancies. Br $\mathcal{f}$ Obstet Gynaecol $1978 ; 85: 582-4$.

${ }^{3}$ Smith ML. Raised maternal serum alpha fetoprotein levels and low birth weight babies. Br $\mathcal{F}$ Obstet Gynaecol 1980;87:1099-102.

${ }^{4}$ Medical Research Council Working Party on Amniocentesis. An assessment of the hazards of amniocentesis. Br $\mathcal{F}$ Obstet Gynaecol 1978;85, suppl 2.

${ }^{5}$ Anonymous. Hazards of amniocentesis [Editorial]. $\mathrm{Br} \mathrm{Med} \mathcal{f}$ 1978;ii: 1661-2.

(Accepted 23 February 1984)

Department of Obstetrics and Gynaecology, Royal Gwent Hospital, Newport, Gwent

J EVANS, MB, MRCOG, registrar

I M STOKES, MRCOG, senior registrar

Correspondence to: Mr I M Stokes, University Hospital of Wales, Heath Park, Cardiff CF4 4XN.

\section{Analgesia in acute pancreatitis: comparison of buprenorphine and pethidine}

The pain of acute pancreatitis is severe, often necessitating opiate analgesia. Pethidine has become the drug of choice, probably because classic teaching held that morphine causes spasm of the sphincter of Oddi. Buprenorphine, a new derivative of thebaine, provides longer analgesia after surgery and more effective pain relief in renal colic than conventional opiates. ${ }^{12}$ We compared buprenorphine and pethidine in the initial management of pain in acute pancreatitis.

\section{Patients, methods, and results}

Thirty two consecutive patients presenting with acute pancreatitis (serum amylase activity $>1200 \mathrm{IU} / 1$ or urinary amylase activity $>3000 \mathrm{IU} / \mathrm{l}$ ) were randomly assigned to receive either intramuscular buprenorphine $(0.3 \mathrm{mg})$ or pethidine $(100 \mathrm{mg})$ from identical ampoules that had been randomly number coded by a computer in the hospital pharmacy. Routine supportive treatment was used. Subsequent analgesia (pethidine $100 \mathrm{mg}$ ) was provided on demand.

About 24 hours after initial administration of the drug pain was assessed on a standard linear analogue scale ranging from 0 to $100^{3}$ Relief of pain was also assessed with an ordered categories scale (no pain $=0$; mild pain $=1$; moderate pain $=2$; severe pain $=3$ ). The duration of pain relief was determined by the patient's demand for further analgesia and was expressed as the mean number of hours free from pain in the first 24 hours after initial analgesia. The severity of the episode of pancreatitis was determined by prognostic factor scoring. ${ }^{4}$ The pain scores were compared with the MannWhitney test, and Fisher's exact test was used to compare the number of patients achieving complete pain relief.

Fifteen patients received pethidine and 17 buprenorphine. The groups were comparable for age and weight. One patient given buprenorphine and two given pethidine had severe pancreatitis. No deaths occurred. The table shows that there was no significant difference between the two groups with respect to the degree of pain before or after analgesia regardless of the method of assessment. The duration of pain relief was comparable in the two groups. Only one patient given pethidine initially and four given buprenorphine did 
not require further analgesia. Nausea or vomiting was a presenting feature of pancreatitis in 11 patients treated with pethidine and 15 with buprenorphine. This settled after analgesia in six and seven patients respectively. Only one patient receiving buprenorphine developed vomiting after administration of the drug. Specific questioning did not elicit any other side effects.

Comparison of median pain scores before and after injection of pethidine and buprenorphine

\begin{tabular}{lcc}
\hline & $\begin{array}{c}\text { Pethidine } \\
(\mathrm{n}=15)\end{array}$ & $\begin{array}{c}\text { Buprenorphine } \\
(\mathrm{n}=17)\end{array}$ \\
\hline Linear analogue scale (range 0-10): & $9 \cdot 1$ & \\
Before injection & $3 \cdot 6$ & $8 \cdot 4$ \\
After injection & $5 \cdot 9$ & 2.5 \\
Difference & $3 \cdot 0$ & $5 \cdot 4$ \\
Ordered category scale (range 0-3): & $1 \cdot 1$ & $2 \cdot 9$ \\
Before injection & $1 \cdot 9$ & 1.1 \\
After injection & $9 \cdot 5$ & 1.6 \\
Difference & $9 \cdot 2$ \\
Duration of pain relief $(\mathrm{h})$ & \\
\hline
\end{tabular}

\section{Comment}

This study shows that pethidine and buprenorphine provide comparable analgesia in acute pancreatitis. Although pethidine has some cost advantage over buprenorphine, it is a controlled and potentially addictive opiate. Potential addiction to narcotics in young adults presenting with recurrent episodes of pancreatitis, often secondary to alcohol abuse, is a cause for concern among clinicians treating this disease. Buprenorphine appears to have little potential for physical dependence ${ }^{5}$ and may be preferred in such patients. Potential objections to buprenorphine include its side effects of vomiting, dizziness, and respiratory depression, which are only partially reversed by naloxone. Respiratory depression was not seen in this study, but anxiety that it may occur may prevent the routine use of buprenorphine in acute pancreatitis, particularly in elderly patients with severe disease.

' Downing JW, Leary WP, White ES. Buprenorphine: a new potent long lasting synthetic analgesic. Comparison with morphine. $\mathrm{Br} \mathcal{F}$ Anaesth $1977 ; 49: 251-4$.

2 Finlay IG, Scott R, McArdle CS. Prospective double-blind comparison of buprenorphine and pethidine in ureteric colic. $\mathrm{Br} \mathrm{Med} \mathrm{F} 1982 ; \mathbf{2 8 4}$ : 1830-1.

${ }^{3}$ Huskisson EC. Measurement of pain. Lancet 1974;ii:1127-31.

- Imrie CW, Benjamin IS, Ferguson JC, et al. A single centre double-blind trial of trasylol therapy in primary acute pancreatitis. Br F Surg 1978;65: $337-41$.

${ }^{5}$ Jasinski DR, Pevnick JS, Griffith JD. Human pharmacology and abuse potential of the analgesic buprenorphine: a potential agent for treating narcotic addiction. Arch Gen Psychiatry 1978;35:501-16.

(Accepted 16 February 1984)

\section{University Department of Surgery, Royal Infirmary, Glasgow G31} 2ER

$S$ L BLAMEY, FRACS, research registrar

I G FINLAY, BSC, FRCS, senior registrar

D C CARTER, MD, FRCS, professor

C W IMRIE, BSC, FRCS, consultant surgeon

Correspondence to: Professor D C Carter.

\section{Human $T$ cell leukaemia virus associated lymphoproliferative disease: report of two cases in Nigeria}

The association between animal leukaemia and retroviruses has long been established but only recently was their human equivalentthe human T leukaemia virus (HTLV)-discovered. ${ }^{1}$ We report features of HTLV positive cases from Nigeria.

\section{Present series}

Nine patients with various forms of malignant lymphoproliferative disorders from Ibadan were sampled and sera tested with an enzyme linked immunosorbent assay for HTLV. ${ }^{2}$ The table summarises the relevant clinical features in each case.

\section{CASE HISTORIES OF HTLV SEROPOSITIVE PATIENTS}

Case 4-A 19 year old Nigerian secondary school student of upper middle class had spent all his life in the metropolitan city of Lagos. Four months before admission he had been diagnosed as suffering from lichen planus, which regressed with topical and systemic corticosteroids. One month later rapidly progressive and generalised nodular skin lesions erupted and he became bedridden. Examination on admission showed nodular violaceous skin lesions and generalised adenopathy without enlarged viscera. Radiographically there was reticulonodular shadowing in both lung fields but no evidence of skeletal lesions. Skin biopsy showed lesions similar to those of mycosis fungoides. The white cell count was $6.2 \times 10^{9} / 1$ and $10 \%$ of the cells were abnormal, resembling the tumour cell bone marrow infiltrate. Cell surfaces of a skin nodule and bone marrow lymphocytes were typed as mature $T$, consistent with a diagnosis of adult $T$ cell leukaemia. Doxorubicin hydrochloride $60 \mathrm{mg} / \mathrm{m}^{2}$ was given. When last seen at six month follow up he was well.

Case 8-This patient was a 57 year old Nigerian petty trader of lower socioeconomic class. On presentation she gave a three month history of progressive weight loss and abdominal swelling. She was moderately emaciated and had generalised adenopathy and an enlarged liver and spleen. Serum calcium concentration measured on a single occasion was normal. Clinically she had chronic lymphocytic leukaemia. She defaulted from follow up after beginning chlorambucil and is believed to have died three months later.

\section{Comment}

These two Nigerian patients had antibodies against HTLV and the clinical features of HTLV associated leukaemia-lymphoma. In one case we documented a $\mathrm{T}$ cell phenotype similar to that in other cases of the virus associated sentinel disease adult $\mathrm{T}$ cell leukaemia. ${ }^{3}$ Thus typical cases of adult $\mathrm{T}$ cell leukaemia have now been documented from Japan, the West Indies, South America, in blacks from the southern United States, and, with this report, for the first time in black Africans. ${ }^{3}$

In our case 1 the patient had skin lesions consistent with cutaneous $T$ cell lymphoma and was HTLV seronegative. This observation confirms that of reports that typical cutaneous $T$ cell lymphoma is only rarely associated with HTLV infection. ${ }^{3}$ The transient occurrence of hypercalcaemia in our case 4 was consistent with reports of this abnormality at various stages in HTLV associated

\begin{tabular}{|c|c|c|c|c|c|c|c|}
\hline Case No & Age and sex & Social class & Habitation & Clinical diagnosis* & Sites affected $\dagger$ & $\begin{array}{c}\text { Immunological } \\
\text { phenotype }\end{array}$ & $\underset{\text { (titre) }}{\text { HTL }}$ \\
\hline 1 & $25 \mathrm{M}$ & Lower & City & CTCL & $\mathrm{LN} / \mathrm{S} / \mathrm{CNS}$ & ND & - \\
\hline $\begin{array}{l}2 \\
3 \\
4\end{array}$ & $\begin{array}{ll}11 & M \\
10 & F \\
19 & M\end{array}$ & $\begin{array}{l}\text { midale } \\
\text { Lower } \\
\text { Lower } \\
\text { Upper } \\
\text { middle }\end{array}$ & $\begin{array}{l}\text { City } \\
\text { City } \\
\text { City }\end{array}$ & $\begin{array}{l}\text { ALL } \\
\text { ALL } \\
\text { ATL }\end{array}$ & $\begin{array}{l}\mathrm{PB} / \mathrm{BM} \\
\mathrm{PB} / \mathrm{BM} \\
\mathrm{L} / \mathrm{S} / \mathrm{PB} / \mathrm{BM} / \mathrm{HC}\end{array}$ & $\begin{array}{l}\text { ? Immature } \mathrm{T} \\
\text { ND } \\
\text { Mature T }\end{array}$ & $+\overline{\overline{(4000)}}$ \\
\hline $\begin{array}{l}5 \\
6 \\
7 \\
8 \\
9\end{array}$ & $\begin{array}{ll}21 & M \\
63 & M \\
25 & M \\
57 & F \\
15 & F\end{array}$ & $\begin{array}{l}\text { Lower } \\
\text { Lower } \\
\text { Lower } \\
\text { Lower } \\
\text { Lower }\end{array}$ & $\begin{array}{l}\text { City } \\
\text { Rural } \\
\text { City } \\
\text { Rural } \\
\text { City }\end{array}$ & $\begin{array}{l}\text { HD } \\
\text { TSS } \\
\text { NHL } \\
\text { CLL ?T } \\
\text { BL }\end{array}$ & $\begin{array}{l}\text { LN/LV/SP } \\
\text { SP } \\
\mathrm{LN} \\
\mathrm{PB} / \mathrm{BM} \\
\mathrm{MS} / \mathrm{BM}\end{array}$ & $\begin{array}{l}\text { ND } \\
\text { ND } \\
\text { ND } \\
\text { ND } \\
\text { ND }\end{array}$ & $\begin{array}{c}\bar{Z} \\
+\overline{(1700)}\end{array}$ \\
\hline
\end{tabular}

*CTCL $=$ Cutaneous T cell lymphoma. ALL = Acutelymphoblastic leukaemia. ATL = Adult T cell leukaemia. HD = Hodgkin's disease. TSS = Tropical splenomegaly syndrome. NHL $=$ Non-Hodgkin's lymphoma. CLL $=$ Chronic lymphocytic leukaemia. BL $=$ Burkitt's lymphoma.

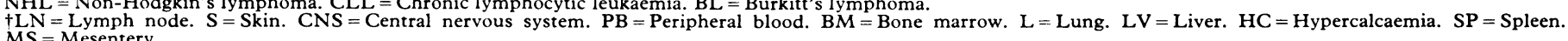
MS = Mesentery.

$\ddagger \mathrm{ND}=$ Not determined.
$\$ \mathrm{Leukaemic}$ and/or bone marrow cells positive by indirect immunofluorescence for mature $\mathrm{T}$ cell markers DA-2, OKT-11A, S33, WT-1, and J-5 and negative for Tdt. 